\title{
Ecological Problem Behind Marine Tourism in Karimunjawa: A Threat to Local Community?
}

\author{
Atika Wijaya ${ }^{1, *}$ Suwito Eko Pramono ${ }^{1,}$ Inaya Sari Melati ${ }^{1,}$ Norol Hamiza Zamzuri ${ }^{2}$ \\ Mohd. Hafiz Hanafiah ${ }^{2}$ \\ ${ }^{1}$ Universitas Negeri Semarang, Kampus UNNES Sekaran, Gunungpati, Semarang, 50229, Central Java, Indonesia \\ ${ }^{2}$ Universiti Teknologi MARA (UiTM), 40450 Shah Alam, Selangor Darul Ehsan, Malaysia \\ ${ }^{*}$ Corresponding author. Email: atika.wijaya@mail.unnes.ac.id
}

\begin{abstract}
This paper describes some ecological problems in Karimunjawa, an island in Java, Indonesia, as the possible impact of tourism activity. This paper, then, focuses on how the local people of Karimunjawa Island face that ecological threat. To answer the problem, we employed qualitative research. Data were collected by in-depth interviews with local tourism business people, local community members, and people from the local government office. In addition, data gathered from observation in Karimunjawa and document analysis. The results show that some ecological problems appear as a result of tourists' activities in Karimunjawa. For example, plastic waste from mineral water and food packaging along the beaches and small islands. Moreover, under the sea also has a problem, such as damaged coral reef. For local people, the awareness of this environmental damage is still low. In the following years, this could be a severe problem as tourism is a significant contribution to the economy of Karimunjawa. This research implies the importance of local awareness of environmental conservation because the community is the subject and the object of tourism development.
\end{abstract}

Keywords: Conservation, Ecological problem, Karimunjawa, Local People, Tourism.

\section{INTRODUCTION}

Karimunjawa Island is an area called "Javanese Bali" because of its exotic natural beauty. The majority of tourism in Karimunjawa depends on its natural resources, such as the sea, beach, and mangrove. The wealth of natural resources and natural beauty is the primary capital in tourism development [1]. However, nature is vulnerable to environmental damage that can result in unsustainable tourist attractions [2]. The negative impact of tourism activities is environmental damage. For example, damage to coral reefs due to diving activities and pollution caused by tourist activities [3], [4].

Although tourism improves the regional economy and community welfare, the awareness of local people to protect the environment is still limited. The beauty and natural wealth of small islands certainly need not be doubted. However, without thinking about sustainable tourism, of course, small island tourism will turn around, destroying the natural beauty and people, most of whom are still poorly educated.
The specific attraction of marine tourism is more diverse attractions from the beach and under the sea [5]. However, that condition leads to a high risk of environmental damage [3]. It is not only about plastic waste at the beaches or damaged coral reefs, but it is also related to increasing noise and water pollution, declining air quality, and biodiversity loss in coastal areas [6]. The environmental problems become a threat for the tourism region itself but also for the people as well. Local people depend on tourism activity for their income and welfare. It means that if the environment in the tourism area is damaged, then tourists decreased, and their income also declines.

Therefore, this paper aims to describe the ecological problems raise in Karimunjawa Island as the impact of marine tourism activities. As we understand, a glimpse of environmental problems in Karimunjawa cannot be avoided [7]. Many studies have been conducted on Karimunjawa Island in various aspects: geographical, social, economic, ecological, and tourism. Next, we also want to describe the seriousness of this environmental 
threat to local people as they depend on their lives on tourism and how they cope with the threats.

\section{RESEARCH METHOD}

This paper employed a qualitative approach that produces descriptions in written or spoken words from people and observable behavior [8]. By employing qualitative, this research is expected to understand the meaning of events and their relation to specific situations. The data will be described in more depth about the ecological threat behind marine tourism in Karimunjawa Islan and how the local people prepared for this threat.

This research is purposively chosen in Karimunjawa Island, Central Java, Indonesia, based on some considerations. First, Karimunjawa Island is a unique tourism destination in small islands. The beautiful natural resources and biodiversity richness above water make both islands are potential for the development of sustainable tourism. Second, the current conventional tourism has impacted the physical environment and society in Karimunjawa.

Data collection was gathered from August to September 2020. The process is very challenging due to the COVID-19 pandemic, Karimunjawa Island is closed to the public, and the main transportation to the island by ship is not every day. So, the data collection keep delayed until August when the island opens for the public and tourists again. We used in-depth interviews with local tourism business people, local community members, and people from the local government office. In addition, data gathered from observation in Karimunjawa and document analysis. The data validation is continuously undertaken during the data collection.

\section{RESULT AND DISCUSSION}

\subsection{Overview of Karimunjawa Island}

Karimunjawa Island is an archipelago located in the Java Sea. Karimunjawa is a subdistrict of the Jepara Regency, consisting of $\pm 1,500$ hectares of land area and $\pm 110,000$ hectares of water. This area has rich biodiversity and natural places protected under Karimunjawa National Park since 1999. The biodiversity on Karimunjawa Island can develop the tourism industry through tourism packages that combine natural and cultural attractions from the local community [9]. Karimunjawa National Park (KNP) is one of the first marine areas in Indonesia to preserve marine biodiversity in Indonesia [3]. Before being known as KNP, this area was designated as a Strict Nature Reserve in 1986, and a decade later, it was officially designated as Karimunjawa National Park. KNP consists of $1101 \mathrm{~km} 2$ of marine, 13 $\mathrm{km} 2$ of tropical lowland forest, and $3 \mathrm{~km} 2$ of mangrove forest [3].
Karimunjawa consists of 27 islands with the population concentrated in the four main islands (Karimunjawa, Kemujan, Parang, and Nyamuk). Most of the inhabitants are small islands. Karimunjawa Island or subdistrict consists of four villages spread in the main land and small islands, i.e., Karimunjawa, Kemujan, Parang, and Nyamuk [10]. The local people mostly work as fishermen because $95 \%$ of Karimunjawa is water. Like any other coastal area, they have to deal with poverty, uncertain income from the sea [11].

However, later on, when tourism is getting popular, many also work in the tourism sector. For instance: guide, open hostel, restaurant, boat, or motorbike rental. Many tourists international and local choose Karimunjawa as the Javanese of Bali, but at a cheaper cost. In Karimunjawa, tourists can enjoy beaches with sunrise or sunset, snorkeling, diving, small islands tour, mangrove trekking. Many tour packages are attached to marine biodiversities, such as diving, snorkeling. The local government supports tourism development. Many infrastructures, such as electricity, road, banks, telecommunication, port, and even airport, are provided to welcome tourists.

\subsection{Ecological Problem in Karimunjawa Island}

The impact of tourism activities on the environment can also affect the quality of life of local communities in the future. It is not impossible; if there is no proper handling, the beautiful environment will be damaged. Based on our research, we found some ecological problems appear in Karimunjawa Island.

First, the bad condition of the coral reefs' ecosystem. The diving and snorkelling activities under the sea and the anchor of tourism boats damaged the coral reef. Every year, the ecosystem of coral reef, seagrass, and mangrove forests gradually declined. It is justified by the research of [9], [12]. It is also caused by the limited knowledge of tourists about coral reef conservation. When doing snorkeling activities, tourists step on coral reefs, even taking valuable coral reefs as souvenirs.

Second, plastic waste along the beach. From our observation, the beauty of beaches in Karimunjawa is a little disturbed by the presence of plastic waste from the drinking bottle or food packaging along the coastline. Tourists spend most of their time enjoying the beach, so they often bring food or drink to the beach. Unfortunately, they forgot to throw trash in its place. Although, we also found trash cans in some spots on the beach.

Although the above condition seems not much, these two problems will be a big problem if not carefully handled. Plastic waste, for example, will disturb other tourists and cause inconvenience to tourists and local 
people. Everyone likes clean beaches to enjoy the natural beauty. Moreover, the damage of coral reefs will affect the sea's biodiversity and detrimental to the fisherman. As stated by Mr. D below,

"If in Karimunjawa the environmental balance has been damaged, this is dangerous, so there is no continuation because that is what we maintain."

\subsection{The Response of Local Community}

Tourism is a human phenomenon means that tourism activities carried out by humans affect human life [13]. Tourism is also a driver of social and cultural change in society. At the same time, tourism is considered a strategic sector that can improve a region's economy. However, the impact of tourism is just as significant. In some cases, tourism marginalizes the local community itself and creates other negative impacts on the community. World tourism trends are changing, and economic growth is no longer a significant issue. The impact of tourism activities such as environmental damage and degradation of the social life of local communities has influenced the paradigm shift in tourism management in the world.

As stated by [14] and [4], the negative impact of tourist activities in KNP. They found that tourists' limited knowledge about snorkeling resulted in damage to coral reefs because they stepped on coral reefs while doing snorkeling activities and even took valuable coral reefs as souvenirs. Moreover, the intensity of the visit has an impact on the condition of the ecosystem. If this condition is not corrected, the next generation of Karimunjawa may lose its natural wealth. Strict proenvironmental policies to limit visitors and activities at sea are possible to reduce ecological damage. In addition, [15] stated that local communities also have wisdom and moral values in conserving and using resources wisely. The role of community leaders, fishers, and even tour guides is significant in spreading the moral values of conservation.

For local people, mainly the guide, they already know how to protect the coral reefs and inform the tourists not to shallow place. As stated by Mr. HS,

"It is not deep; we are only allowed on the surface. We cannot snorkel shallow. Our size should be even deeper. If too shallow, we will touch coral reefs. The coral reefs will be damaged or scratched."

The development of fishpond also attracts the anxiety of local people as they are more concerned about environmental sustainability. Mr. D stated,

".... that is why we reject ponds. These ponds damage the environmental ecosystem. This is inversely proportional; on the one hand, the government wants to develop Karimunjawa as a sustainable concept but indirectly, the government has also sacrificed by allowing entrepreneurs. When we have seen Karimun, the city is no longer growing by making threats to development that is already protruding, which means it is omission."

\section{CONCLUSION}

The marine tourism in Karimunjawa island wellknown as an exotic place in Java which like Bali. The natural beauty is vulnerable; many tourists not always bring money but also waste and pollution. Our research shows that the most significant environmental problems are the vulnerable coral reefs damaged due to diving and snorkeling activities. Then, much plastic waste along the coastline. The local people, including the guide tourists, already inform the tourists. They also have the proper knowledge to conserve the environment. Overall, the problems above might not cause an extreme threat to the local people of Karimunjawa, but a sign to raise awareness about the ecological problem. This research asked the stakeholders to pay attention to the ecological problems as part of sustainable tourism development.

\section{ACKNOWLEDGMENTS}

The authors gratefully acknowledge the support of the Ministry of Education and Culture of Indonesia and Universitas Negeri Semarang in providing the Research Fund (Project Number: 97.234/UN37/PPK.3.1/2020). This research is a collaboration research scheme between Universitas Negeri Semarang (UNNES), Indonesia, and Universiti Teknologi MARA (UiTM), Malaysia.

\section{REFERENCES}

[1] I. G. Pitana and P. G. Gayatri, Sosiologi Pariwisata. Yogyakarta: ANDI, 2005.

[2] V. Reyes-García et al., "Local indicators of climate change: The potential contribution of local knowledge to climate research," Wiley Interdiscip. Rev. Clim. Chang., vol. 7, no. 1, pp. 109-124, 2016, doi: 10.1002/wcc.374.

[3] S. J. Campbell, T. Kartawijaya, I. Yulianto, R. Prasetia, and J. Clifton, "Co-management approaches and incentives improve management effectiveness in the Karimunjawa National Park , Indonesia," Mar. Policy, vol. 41, pp. 72-79, 2013, doi: 10.1016/j.marpol.2012.12.022.

[4] A. N. Laksono and Mussadun, "Dampak Aktivitas Ekowisata di Pulau Karimunjawa Berdasarkan Persepsi Masyarakat," J. Tek. $P W K$, vol. 3, no. 2, pp. 262-273, 2014, [Online]. Available: http://ejournals1.undip.ac.id/index.php/pwk.

[5] W. Gladstone, B. Curley, and M. R. Shokri, "Environmental impacts of tourism in the Gulf and the Red Sea," Mar. Pollut. Bull., vol. 72, no. 
2, pp. 375-388, 2013, doi:

10.1016/j.marpolbul.2012.09.017.

[6] L. Zhong, J. Deng, Z. Song, and P. Ding, "Research on environmental impacts of tourism in China: Progress and prospect," J. Environ. Manage., vol. 92, no. 11, pp. 2972-2983, 2011, doi: 10.1016/j.jenvman.2011.07.011.

[7] A. Wijaya, S. E. Pramono, I. S. Melati, N. H. Zamzuri, M. H. Hanafiah, and A. R. Ghazali, "Toward the Community-based Sustainable Marine Tourism," Int. J. Acad. Res. Bus. Soc. Sci., vol. 11, no. 5, pp. 261-275, 2021, doi: 10.6007/IJARBSS/v11-i5/9924.

[8] L. J. Moleong, Metode Penelitian Kualitatif. Bandung: PT. Remada Rosdakarya., 2014.

[9] S. E. Priyanto, "Dampak Perkembangan Pariwisata Minat Khusus Snorkeling Terhadap Lingkungan: Kasus Destinasi Wisata Karimunjawa," J. Kepariwisataan, vol. 10, no. 3, pp. 12-28, 2016.

[10] B. P. S. K. Jepara, "Kecamatan Karimunjawa Dalam Angka 2018," Jepara, 2019.

[11] B. Setiawan, R. Rijanta, and M. Baiquni, "Poverty and Tourism: Strategies and Opportunities in Karimunjawa Island, Central Java," J. Indones. Tour. Dev. Stud., vol. 5, no. 2, pp. 121-130, 2017, doi:

10.21776/ub.jitode.2017.005.02.08.

[12] F. Limbong and S. Soetomo, "Dampak Perkembangan Pariwisata Terhadap Lingkungan Taman Nasional Karimunjawa," Ruang, vol. 2, no. 1, pp. 351-360, 2014.

[13] I. G. Ardika, Kepariwisataan Berkelanjutan: rintis jalan lewat komunitas. Jakarta: Kompas Media Nusantara, 2018.

[14] F. Limbong and S. Soetomo, "Dampak Perkembangan Pariwisata Terhadap Lingkungan Taman Nasional Karimunjawa," Ruang J. Perenc. Wil. dan Kota, vol. 2, no. 1, pp. 51-60, 2013.

[15] S. Sri Endang P., "Scientific Knowledge Based Culture and Local Wisdom in Karimunjawa for Growing Soft Skills Conservation," Int. J. Sci. Res., vol. 4, no. 9, pp. 2319-7064, 2013, [Online]. Available: www.ijsr.net. 